This item was submitted to Loughborough's Research Repository by the author.

Items in Figshare are protected by copyright, with all rights reserved, unless otherwise indicated.

The feasibility of renewable energy sources for pumping clean water in subsaharan Africa: a case study for Central Nigeria

PLEASE CITE THE PUBLISHED VERSION

http://dx.doi.org/10.1016/j.renene.2010.12.019

PUBLISHER

(c) Elsevier

VERSION

AM (Accepted Manuscript)

LICENCE

CC BY-NC-ND 4.0

REPOSITORY RECORD

Cloutier, Michael, and Paul Rowley. 2019. "The Feasibility of Renewable Energy Sources for Pumping Clean Water in Sub-saharan Africa: A Case Study for Central Nigeria”. figshare. https://hdl.handle.net/2134/13055. 
This item was submitted to Loughborough's Institutional Repository (https://dspace.lboro.ac.uk/) by the author and is made available under the following Creative Commons Licence conditions.

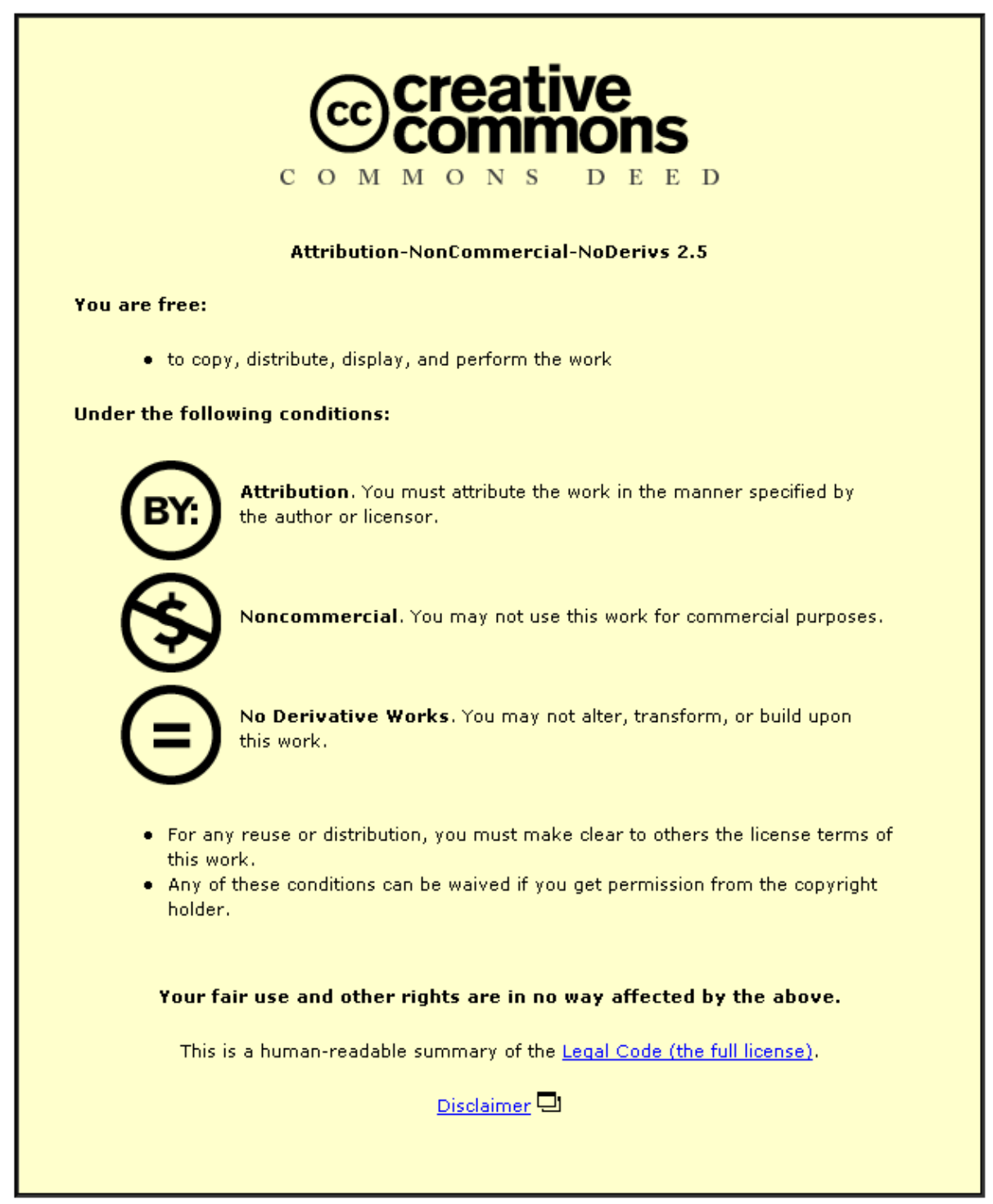

For the full text of this licence, please go to: http://creativecommons.org/licenses/by-nc-nd/2.5/ 


\title{
The Feasibility of Renewable Energy Sources for Pumping Clean Water in Sub-Saharan Africa: a Case Study for Central Nigeria
}

\author{
Michael Cloutier and Paul Rowley (corresponding author), \\ CREST (Centre for Renewable Energy Systems Technology), Loughborough University, \\ Leics. LE11 3TU UK. Email P.N.Rowley@lboro.ac.uk
}

\begin{abstract}
With less than $6 \mathrm{~mm}$ of rain from November through February every year, the central regions of Nigeria are in acute need of safe and consistent water supplies for drinking and other domestic or agricultural uses. Borehole supplies are capable of meeting a significant proportion of water needs, but ongoing fuel costs to power a generator and pump add a heavy burden to already disadvantaged communities. In this study, a techno-economic analysis is carried out in order to assess the feasibility of renewable energy sources and technologies to substitute for fossil-fuel powered pumping platforms. The results indicate that there is sufficient solar resource throughout these regions to facilitate relatively cost effective water pumping solutions, as well as a potentially effective wind resource depending on the exact location of the pumping station. Although systems based on these resources have high capital costs compared to a petrol or diesel-based platforms, over a 20-year project life the analysis indicates that ongoing fuel costs for a fossil-fuel-based system greatly outweigh the increased up-front costs of renewable alternatives. In conclusion, the results indicate that if the water demand at a particular site exceeds the capabilities of a hand pump, a renewable energypowered pumping system is an attractive option, both economically and logistically in comparison to fossil-fuel-powered alternatives.
\end{abstract}

Keywords: Techno-ecomonic analysis, Nigeria, borehole, water pumping, renewable energy, solar pump, wind pump.

\section{INTRODUCTION}

\subsection{Background}

In the rural regions of central Nigeria, including the states of Plateau, Bauchi, and Kaduna, an agricultural subsistence economy predominates with a growing season defined by rainfall patterns. Precipitation peaks above $300 \mathrm{~mm}$ in August and then reduces to below $6 \mathrm{~mm}$ for November, December, January, and February combined [1]. In these winter months, agricultural production is greatly reduced and water for drinking, cooking, washing, and bathing becomes extremely scarce. In these regions, water is obtained predominantly from streams and open wells which often dry up during the winter months, and therefore water conservation is an imperative [2]. Furthermore, when surface water resources are available, they are often contaminated, and can cause water borne illnesses such as cholera. According to the World Health Organization (WHO) such diarrhoeal diseases, caused by unsafe water supply, sanitation and hygiene, account for approximately 119,700 deaths in Nigeria each year [3]. Additionally, streams and other surface water resources are often a considerable distance away from villages, and the terrain can be dangerous to traverse, especially while manually transporting a large volume of water. In such locations, women and children will make early morning journeys of up to $10 \mathrm{~km}$ to obtain water, with subsequent journeys being required again throughout the day, which interfere with education and other activities.

To confront these issues, community boreholes can provide a safe and convenient water supply. When the water demand from borehole supplies is greater than a hand pump can provide, an electric pump is commonly used. However grid electricity is rarely available and inconsistent when it is, so petrol or diesel generators are used. This burdens the already struggling communities with ongoing fuel and maintenance costs. In addition, fuel supplies can be intermittent. To overcome these issues, 
governments, NGOs and charities are exploring the potential of using renewable technologies to power water pumps at less of an ongoing financial burden.

\subsection{Objectives}

The purpose of this study is to determine the feasibility of using renewable energy to replace petrol as a source for pumping water by:

- Identifying and quantifying the sources of renewable energy suitable for powering a borehole pumping system in the rural regions of the Plateau, Kaduna, and Bauchi states.

- Identifying or designing suitable systems to use those sources in Jos, Plateau State to pump water from a borehole with typical specifications and water demands for the region.

- Performing a techno-economic analysis of those systems comparing them to the traditional petrol generator/electric pump system, to determine which would be most suitable.

\subsection{Precedents}

In the developing world, hand pumps are the most common source for pumping water and when their capabilities are exceeded generators and/or grid electricity are then used [4]. Of the renewable resources, solar energy is the most commonly used source to pump water due to the abundant and consistent resource in these mostly subtropical regions [5]. This is especially true of Nigeria and other sub-Sahara African countries [6]. Wind energy has been used for centuries to pump water for drinking, irrigation and drainage, and today is used widely in African regions such as Egypt and Kenya as well as in Middle Eastern regions such as Jordan and Oman where the average wind speeds are often in a favourable range of 5-7m/s $[7,8,9,10]$. Hydropower, biomass, and biofuels can also provide feasible sources of energy to pump water with however their use is less prominent due to their inconsistent supplies in the developing world [4].

Several studies show that some renewables can be economically favourable compared to diesel generators for pumping water in the developing world. In Sudan, wind-mechanical systems were found to be less expensive than diesel systems, however wind-electric systems were not [11]. Similar results have been shown in Jordan and India, as well as the economic favourability of PV systems over diesel $[12,13]$. The potential of a renewable energy system is highly dependent on the available resource, which can vary greatly from region to region. One study in southern Nigeria evaluated PV in comparison with diesel for rural electrification and found that PV was not competitive [14]. However, the solar resource available in southern Nigeria is significantly lower than that in central regions.

\section{RENEWABLE ENERGY RESOURCE ASSESSMENT}

To determine the feasibility of a renewably-powered pump, the available energy sources in central Nigeria must be quantified. This information was obtained and verified via both analysis of available data (such as from wind and solar atlases) and site visits to the town of Jos and nearby villages in Plateau State. The results are summarised below.

\subsection{Manual Pumping}

Human power, specifically for hand pumping, is estimated to be $50-75 \mathrm{~W}$ at a comfortable level for a prolonged period of time. However, with each person filling only one or two buckets before moving on, a much higher level could be sustained throughout the day [4]. The limitations on hand pumping then fall mostly on the efficiency of the pump. The Afridev pump used widely around Africa achieves discharge rates of $0.8-1.35 \mathrm{~m}^{3} / \mathrm{h}$ at depths of $15-45 \mathrm{~m}$ [15]. Therefore, for a $30 \mathrm{~m}$ borehole, which is typical of such projects, a discharge rate of approximately $1 \mathrm{~m}^{3} / \mathrm{h}$ can be achieved. Hand pumps are often operated up to 12-16 hours per day, but since they are not used continuously, an effective 
operating time of 6-8 hours per day can be assumed [4]. In these situations water volumes of 6-8 $\mathrm{m}^{3} /$ day is achievable.

Hand pumps are also useful in villages with a widely distributed population, as is the case in Chokobo. A borehole and hand pump has been installed and although the population of the village is approximately 4,000-5,000, the hand pump is unused for most of the day. Because the village is spread out over such a wide area, most of the settlements utilised the often contaminated water from more closely situated streams and open wells. In cases like these, the installation of several boreholes throughout the village with hand pumps would be more effective than pumping large volumes of water from a single borehole.

\subsection{Hydropower}

Rivers, streams and other bodies of water can often provide an effective and inexpensive energy source for pumping clean water using ram pumps, turbines, or river-current pumps [4]. In the central regions of Nigeria these bodies of water are highly variable if they exist at all, and are not always in close enough proximity to the pumping site. For these reasons, hydropower is not considered in this study.

\subsection{Wind Energy}

The wind speeds for the cities of Jos, Bauchi and Kaduna are shown in Table 1 at a height of $15 \mathrm{~m}$ and assuming a flat terrain with a roughness length of $0.06 \mathrm{~m}$ which is associated with the high grass and crops typical of these regions. As shown, the wind resources in these Nigerian locations are not as favourable as in the countries of Egypt and Kenya.

Table 1: Wind Resource at a Height of 15m [16,17]

As a benchmark, effective electricity generation from wind energy requires an average wind speed greater than $5 \mathrm{~m} / \mathrm{s}$. However, for wind-mechanical pumps, lower wind speeds can be sufficient [18]. Even with an average wind speed as low as $2.5 \mathrm{~m} / \mathrm{s}$, wind-mechanical pumping can still be economically feasible [19]. For these reasons, only wind-mechanical systems are considered in this study.

Generally an average annual wind speed greater than $3.5 \mathrm{~m} / \mathrm{s}$ and an average wind speed in the least windy month of more than $2.5 \mathrm{~m} / \mathrm{s}$ is required as a feasible resource for mechanical wind pumping [4]. This would rule out Kaduna and Bauchi as potential sites. However, Jos has an effective wind resource with which to pump water. In reality, wind characteristics are highly variable depending greatly on local climate and topography, and a detailed assessment of the exact site should be performed before embarking on any wind energy project.

The other caveat to using wind energy is that wind system supply chain in Nigeria is currently underdeveloped; during the research for this study no companies in Nigeria were found that could actually supply or install a wind system. For this reason the availability of a wind pumping system should be ensured before considering wind energy as an option. Alternatively, there may be a business opportunity in bringing wind pumping technology to Nigeria.

One of the benefits of wind-mechanical systems is their simplicity, and Schumacher states that for a solution to be appropriate and sustainable it should employ local skills and material resources [20]. Wind pumps could easily be assembled and maintained using the materials and skills available in the villages and cities of Nigeria, which makes them an attractive option for a truly sustainable solution. 


\subsection{Solar Energy}

In general, an average daily solar radiation of at least $4.0 \mathrm{kWh} / \mathrm{m}^{2}$ and more than $3.5 \mathrm{kWh} / \mathrm{m}^{2}$ per day in the least sunny month are required for a feasible solar pumping system [4]. The mean daily global solar radiations for the cities of Jos, Kaduna and Bauchi are shown in Table 2. As indicated, with a mean daily global solar radiation of $4.39 \mathrm{kWh} / \mathrm{m}^{2}$ in the cloudiest month, these regions of Nigeria are ideal for solar powered systems, and with several companies in the Jos region offering solar PV power technologies it is already widely being used for street lighting, water pumping, and refrigeration.

Table 2: Solar Resource in Central Nigeria [6,21]

A further benefit of solar PV powered systems is that the seasonal variation in solar radiation match water demand; in the dry season when there is more water used there is a greater solar resource than in the wet season when there is a lower resource and less water used [2].

\subsection{Biomass and Biofuels}

There are two factors that make the use of biomass energy to pump water an inappropriate solution in rural Nigeria. The technologies needed to convert biomass energy to a form suitable for pumping water, namely gasifiers, require local technical skills and operating labour that are not available in these rural settings. Secondly, villages in the rural regions are already using biomass at an unsustainable rate for cooking, often purchasing it or walking several kilometres each day in search of biomass supplies. Although the climate and land is suitable for growing biomass crops, those villages already operating on a subsistence basis would then suffer from a potential decrease in food crops. They could experience land pressures to grow both food and biomass, but more likely they would lack the human capacity to grow both. This is also the case for biofuel cultivation, where the land is suitable for growing fuel crops such as oil palm and cassava, but is also of great value for food crop cultivation. Furthermore, these regions also currently lack the skills and available labour to process the crops into oil or alcohol [22].

Although growing and processing palm oil is not currently feasible for these communities, purchasing it to use in diesel generators may be. Nigeria is one of the largest palm oil producers in the world and diesel generators can exhibit the same performance using palm oil as an alternative fuel [23]. With the probability of rising fuel prices in the future, purchasing palm oil to use as an alternative fuel may become a financially attractive option.

\section{CANDIDATE SYSTEMS: DESIGN AND ANALYSIS}

The following systems are designed for the material and energy resources available in the Jos region of Nigeria, and therefore may vary for other regions. The only exception to this is the wind system which is based on a wind pump not currently available commercially in Nigeria. In this case the assumption made is that the wind pump was either imported or manufactured locally. The systems are based on a pre-drilled borehole with a total effective head of $40 \mathrm{~m}$ and a maximum flow rate of 0.57 litres/s. With the exception of the hand pump, the systems were designed for three daily water demands; 10, 20 and 30 cubic metres per day. These characteristics and requirements are typical for borehole systems in the region.

\subsection{Hand Pump Based Systems}

These systems require only that an Afridev or similar type hand pump be installed on the borehole. The hand pump system is capable of providing up to 8 cubic metres per day, and as individuals fill their own personal vessels, mass storage is not required.

\subsection{Petrol Generator Based Systems}


These systems commonly make use of a $0.5 \mathrm{hp}$ Matra submersible pump powered by a Honda 5000 or similar generator with a rated output of $4.5 \mathrm{~kW}$. Although during steady state operation the pump will use only a fraction of the generator's rated power it is necessary for the pump's start up requirements of $16 \mathrm{~A}$ at $230 \mathrm{VAC}$, and a $4.5 \mathrm{~kW}$ generator is the smallest size available that will satisfy this. The pump is chosen for providing a discharge rate similar to the borehole's maximum flow rate at an effective head of $40 \mathrm{~m}$. The water is pumped into an above ground tank with 2 days storage capacity and for pumping at the maximum flow rate of 0.57 litres/s the pump will be run daily for 5, 10 or 15 hours to provide a daily water supply of 10,20 or 30 cubic metres per day respectively.

\subsection{Solar PV Based Systems}

A typical solar pumping system is shown in Figure 1. The solar PV-based systems are designed to provide each of the daily water requirements in the least sunny month of August, for which the mean daily horizontal radiation in Jos is $4.65 \mathrm{kWh} / \mathrm{m}^{2}$. To optimize the systems over the entire year, the arrays should face south with an inclination of $15^{\circ}$. However, the PV systems have been optimized for the summer months with an inclination of $0^{\circ}$ to maximize daily output during this time, as this is the critical period for water availability.

Figure 1: Example Solar Pumping System [24]

The PV system has been designed with the following major components as they are available within the region:

- Grundfos SQF 2.5-2 Submersible Solar Pump

- Kyocera KC70 70W poly-Si Solar Modules

In designing these systems the following assumptions were made:

- Free horizon with no shading, which may be an optimistic assumption

- Array output loss of 5\% to allow for module mismatch and cable and diode losses

- 4 days worth of water storage is required to compensate for consecutively cloudy days

\section{$3.3 .11^{3} \mathrm{~m}^{3} /$ day System}

Direct pumping systems are the norm in Nigeria up to a capacity of around 10 cubic metres per day, therefore neither a battery or charge controller are required for this system. In the absence of a PV design software package capable of handling the dynamic load of the specialized solar pump, this system was designed using mean hourly global irradiation data for the month of August along with efficiency data for Kyocera's modules and performance curves for Grundfos' pumps. With these tools the average daily water output for a 12 -module $840 \mathrm{~W}_{\mathrm{p}}$ system could be determined as shown in Figure 2. With a mean total of $29.4 \mathrm{kWh}$ of radiation incident over the 12 -module array throughout the day, $2.6 \mathrm{kWh}$ are generated by the system to pump 10.34 cubic metres of water. The details of this system are shown in Table 3 . While providing the required 10 cubic metres per day in the least sunny month of August, this system will deliver 15.8 cubic metres per day in the sunniest month of February. The village of Bauchi would also require an $840 \mathrm{~W}_{\mathrm{p}}$ system to deliver 10 cubic metres of water however Kaduna, with a lesser solar resource, would require a larger system of $980 \mathrm{~W}_{\mathrm{p}}(14$ modules) to ensure 10 cubic metres per day.

Figure 2: Global Irradiation, 12-Module 840WP System Output, and Pump Discharge for an Average Day in August [21,25,26] 
Table 3: 10m3/day System Details

\subsubsection{0m3/day and 30m3/day Systems}

As the solar PV-based systems are limited by both the maximum flow rate of the borehole $(0.57$ litres/s) and the number of hours the sun is available, water requirements of 20 and 30 cubic metres per day cannot be met by a direct pumping system. Therefore battery storage is required to continue pumping once the sun has gone down. To control the charging of the batteries a charge controller will also be required.

In designing systems with battery storage the following is assumed:

- Battery efficiency of $85 \%$

- Controller efficiency of $90 \%$

- Maximum battery depth of discharge of $80 \%$

- Smallest battery available in Jos is 200Ah at 12 VDC

With these systems direct pumping will occur throughout the day until the pump reaches its maximum discharge rate of $2.2 \mathrm{~m}^{3} / \mathrm{h}$, which occurs when the array output exceeds $500 \mathrm{~W}$. When this happens the extra energy will be stored in the batteries until the sun goes down, at which point it will be used to continue the operation of the pump. The systems required to pump 20 and 30 cubic metres per day are detailed in Table 4 and Table 5 respectively.

Table 4: $20 \mathrm{~m}^{3} /$ day System Details

Table 5: $30 \mathrm{~m}^{3} /$ day System Details

As the solar resource in Bauchi is greater than in Jos, a suitable PV system would require only 22 modules to provide 20 cubic metres per day and 34 modules to deliver 30 cubic metres per day. In Kaduna, where there is a lesser resource, a system needs 26 and 40 modules to ensure 20 and 30 cubic metres per day respectively. Systems at both locations would still require the same battery storage capacity as in Jos.

\subsection{Wind Based Systems}

These systems are based on the Kijito mechanical wind pump, shown in Figure 3, which is developed and manufactured in Kenya by Bob Harries Engineering. At the time of this study, neither the Kijito nor any wind pump were available in Jos, and therefore these systems are based on the Kijito being imported to Nigeria or a similar system being manufactured locally. The systems are sized to suit the wind characteristics in Jos. However, the wind resource is highly dependent on local conditions, and therefore this system is simply an example of what is possible in Jos. In practice the system should be designed around a detailed assessment of the exact site where the wind pump will be installed, including at least 12 months of measured wind data.

In sizing these systems the following assumptions were made:

- A tower height of $15 \mathrm{~m}$

- Rotor sizes based on standard available Kijito sizes

- Flat terrain with roughness length of $0.06 \mathrm{~m}$

- 6 days worth of water storage is required to compensate for consecutively windless days 
Using performance data from Bob Harries Engineering for the Kijito, the rotors were sized to provide the required water capacity in the least windy month of October when the average wind speed in Jos is $3.7 \mathrm{~m} / \mathrm{s}$. The sizes and outputs for the 10,20, and 30 cubic metre systems are detailed in Table 6 .

Figure 3: Example Kijito Wind Pump [10]

Table 6: Wind Pump Systems [27]

With a low average wind speed of $2.3 \mathrm{~m} / \mathrm{s}$ in the least windy month, both Kaduna and Bauchi do not have the resource required to pump water with wind energy. Therefore these systems are only valid for Jos and locations with similar conditions.

\section{TECHNO-ECONOMIC COMPARITIVE ANALYSIS}

In comparing the above systems, a Net present cost (NPC) analysis was performed where the following assumptions were made:

- Project life of 20 years

- Annual inflation rate of $24.8 \%$ based on the average rate in Nigeria from 1987 to 2006 [28]

- Fuel prices rise with inflation, which is an optimistic estimate as fuel prices actually increased in Nigeria by 31.8\% annually on average from 1988-2007 [29]

- Discount rate of 5\% [14]

- No end of project salvage is considered

With the exception of the wind systems, all costs in this analysis are based on prices obtained from suppliers in Jos. Wind system costs are based on prices in Kenya given by Bob Harries Engineering for the Kijito wind pump [27]. As neither the Kijito nor any other wind pumps are currently available commercially in Nigeria, this analysis assumes the development of a wind energy market either by importing the Kijito or manufacturing a similar system locally.

\subsection{Initial Capital Costs}

The initial capital costs are the total funds needed upfront to implement a system. For all systems in this study the following capital costs are included:

- Borehole drilling

- Pump

- Storage tank, tower, and all piping

- Breaker switch and all electrical

- Security to prevent theft and vandalism

- Installation

- Transport of materials and workers to the site

In addition, the petrol systems include the cost of the generator, the solar PV systems include costs for modules, array mounting, and batteries and a charge controller where required, and finally the wind systems include the rotor machine, tower, and all mechanisms required.

The initial capital costs for the systems are shown in Figure 4, with all figures given in thousands of Nigeria Naira (\#). As of July 2010, one US dollar was exchanging for 150 Naira (\#150).

Figure 4: Initial Capital Costs 
When comparing capital costs the petrol systems appear attractive as their costs are only a fraction of those for the solar and wind systems. At $\$ 5.7-5.8$ million to implement a $30 \mathrm{~m}^{3} /$ day wind or solar system versus 1.7 million for a petrol system of the same capacity, solar and wind seem unlikely options. The disparity between the costs arises from the equipment needs of the systems. The capital costs of a petrol system are dominated by the borehole installation and a storage tank, where the actual generator is relatively inexpensive. The solar and wind systems on the other hand require relatively expensive equipment for generation such as solar modules and a wind turbine. In addition, due to the variable nature of solar and wind energy, a greater storage capacity is required; four and six days worth of water for solar and wind respectively versus only two days for the petrol generator. This significant storage capacity greatly increases the equipment costs. To give some perspective, the initial capital costs of a hand pumping system capable of $8 \mathrm{~m}^{3} /$ day are approximately $\$ 562,000$.

\subsection{Cost of Water}

The cost of water (CoW) is measured in $\# / \mathrm{m}^{3}$ and is determined by:

$$
\text { CoW }=\frac{\text { NPC of Project over } 20 \text { Years }(\#)}{\text { Water Obtained over } 20 \text { Years }\left(\mathrm{m}^{3}\right)}
$$

where the Net present cost (NPC) includes not only the initial capital costs but also the ongoing operating costs over the life of the project, which are subject to inflation and discounting. For all systems the following operating costs are included:

- Borehole maintenance every 5 years

- Annual pump maintenance

- Annual maintenance of the tank, security, and piping

In addition, the petrol systems include the annual cost of fuel and generator maintenance, and generator replacement every 5 years, the solar systems include annual PV inspection and maintenance, battery replacement every 5 years, and pump replacement and charge controller rebuilding every 10 years, and finally the wind systems include annual maintenance of the rotor machine, tower, and all mechanisms.

In calculating fuel costs for the petrol generator, it was assumed that except for at start up when the full capacity of the generator is needed, it would otherwise operate at $1 / 4-10 a d$. As defined in the generator specifications, the fuel consumption at this load is 1.12 litres $/ \mathrm{h}$. The $\mathrm{CoW}$ for these systems over 20 years is shown in Figure 5.

\section{Figure 5: Cost of Water Over 20 Years}

Although the solar and wind systems initially appear unattractive when comparing capital costs, the total project costs over a 20 -year life give a wholly different perspective. After initial implementation, all three systems have relatively low ongoing costs in the form of maintenance and occasional equipment replacement. However, the petrol system is also burdened with the cost of fuel, and because of this significant extra expense, water from the petrol systems will cost $\$ 485$-538 for each cubic metre over 20 years, 3-5 times as much as from a solar or wind system, both of which can provide 30 cubic metres of water per day for $\$ 102$ per cubic metre. This makes the wind and solar systems highly attractive in comparison to the petrol systems from the standpoint of overall project costs. However, the initial capital required for the solar and wind projects must still be considered as it 
may be difficult to obtain. In comparison, the CoW for a hand pumping system capable of $8 \mathrm{~m}^{3} / \mathrm{day}$ is $41 \mathrm{~A} / \mathrm{m} 3$.

\subsection{Effects of Inflation and Discount Rate}

The economic conditions within Nigeria will greatly influence the NPC of a project over 20 years. The inflation and discount rates used in this study are only estimates based on historical data, and potential changes in their value could have a significant impact on the cost of a project. Figure 6 and Figure 7 show the sensitivity of these projects to inflation and discount rate by showing their effect on the CoW for the $20 \mathrm{~m}^{3} /$ day systems.

Figure 6: Effects of Inflation on the Cost of Water for the $20 \mathrm{~m}^{3} /$ day Systems

Figure 7: Effects of Discount Rate on the Cost of Water for the 20m3/day Systems

As shown, variations in both inflation and discount rates have a greater effect on the viability of the petrol system than both the solar and wind systems. An increase in the average annual inflation rate from $0 \%$ to $30 \%$ will see an approximate $150 \mathrm{~m} / \mathrm{m}^{3}$ rise in the cost of water for the solar and wind systems, while the same will cause an $850 \mathrm{~N} / \mathrm{m}^{3}$ rise for the petrol system. The same cost increase can also result from a decrease in the discount rate from $15 \%$ to $0 \%$. These effects are due to the majority of the NPC for the solar and wind systems being accounted for in the initial capital costs. The petrol system on the other hand has relatively low capital costs and therefore the majority of the NPC is in the ongoing operating costs, which are subject to inflation and discount rate. It is interesting to note that at no point does the petrol system become economically favourable over the other two systems. This is also assuming that fuel prices rise at the same rate as inflation, which is optimistic. If fuel rises at a higher rate it will only increase this disparity. To give some perspective, both the UK and the USA have had an average annual inflation rate of about $3 \%$ over the past 20 years, with fuel prices increasing by $5.5 \%$ per annum in the USA over the same period $[28,30]$.

\section{CONCLUSIONS}

In the region of Jos both solar based systems with and without battery storage and wind systems based on the Kijito wind pump from Kenya were found capable of delivering the required daily water demands of 10,20, and 30 cubic metres. Although the initial capital costs of these systems are significantly more than for petrol based systems, their net present cost over a 20 -year project life is only a fraction of that for the petrol systems because of the latter's ongoing fuel costs. The solar based systems had the lowest overall cost when comparing the three technologies and are the best option for a water pumping system. The overall costs for a wind system were not significantly greater than for solar however there are several factors which make them a less favourable option; namely the absence of wind system suppliers in Nigeria and a generally weak wind resource which changes significantly with location. The demands of the site should be adequately assessed to ensure the appropriate system is being implemented. In a village with a widely distributed population, it may be more effective and economically favourable to drill several boreholes throughout the area and use hand pumps, rather than installing one borehole with a high volume solar pump.

\section{ACKNOWEDGEMENTS}

The author acknowledges with gratitude the assistance of John Akila and the people of Chokobo, Thomas Gata and the people of TASTE Nigeria, and Asaleye Adeyemi of Ashdam Solar Nigeria for their assistance during the site visit to Jos. Sincere appreciation is also offered to Ben Udejiofo and the people of TASTE UK, Solar Electric Systems Nigeria, Solar Electric Light Fund and Monica Samec of the Council for Renewable Energy in Nigeria for their assistance in completing this study. 


\section{REFERENCES}

[1] National Climatic Data Center, Global Historical Climatology Network (GHCN), Version 1, 1990, [online], (updated 12 Sep 2003), Available from: http://www.worldclimate.com/, [cited 4 Sep 2007].

[2] K.O. Adekalu et al, "Water sources and demand in South Western Nigeria: implications for water development planners and scientists", Technovation, Vol. 22, 2002, pp. 799-805.

[3] L. Fewtrell et al, "Sanitation and hygiene - Quantifying the health impact at national and local levels in countries with incomplete water supply and sanitation coverage", World Health Organization Environmental Burden of Disease Series, Vol. 14, 2007.

[4] E.H. Hofkes and J.T. Visscher, Renewable Energy Sources for Rural Water Supply, International Reference Centre for Community Water Supply and Sanitation, The Hague, 1986.

[5] A. Kumar and T.C. Kandpal, "Renewable energy technologies for irrigation water pumping in India: A preliminary attempt towards potential estimation”, Energy, Vol. 32, 2007, pp.861-870.

[6] J.O. Ojosu, "The iso-radiation map for Nigeria", Solar \& Wind Technology, Vol. 7, No. 5, 1990, pp. 563-575.

[7] M.S. Mohsen and B.A. Akash, "Potentials of wind energy development for water pumping in Jordan", Renewable Energy, Vol. 14, Nos. 1-4, 1998, pp. 441-446.

[8] Z. Al Suleimani and N.R. Rao, "Wind-powered electric water-pumping system installed in a remote location", Applied Energy, Vol. 65, 2000, pp. 339-347.

[9] A.S. Ahmed Shata and R. Hanitsch, "Evaluation of wind energy potential and electricity generation on the coast of Mediterranean Sea in Egypt", Renewable Energy, Vol. 31, 2006, pp. 11831202.

[10] W. Ogana, "Wind energy development in Kenya - A Review", Solar \& Wind Technology, Vol. 4, No. 3. 1987, pp. 291-303.

[11] N.A. Gadah El Dam, "Financial-economic analysis of wind and diesel driven water pumping systems in Sudan", Renewable Energy, Vol. 5, Part I, 1994, pp. 653-657.

[12] M. Hammad, "Photovoltaic, wind and diesel: A cost comparative study of water pumping options in Jordan", Energy Policy, Vol. 23, No. 8, 1995, pp. 723-726.

[13] I. Odeh, Y.G. Yohanis, B. Norton, "Economic viability of photovoltaic water pumping systems", Solar Energy, Volume 80, Issue 7, July 2006, Pages 850-860

[14] O.U. Oparaku, "Rural area power supply in Nigeria: A cost comparison of the photovoltaic, diesel/gasoline generator and grid utility options", Renewable Energy, Vol. 28, 2003, pp. 2089-2098.

[15] Skat Foundation, Installation and Maintenance Manual for the Afridev Handpump, Revision 1, Skat Foundation, 2003.

[16] L.O. Adekoya and A.A. Adewale, "Wind Energy Potential of Nigeria", Renewable Energy, Vol. 2, No. 1, 1992, pp. 35-39.

[17] J.O. Ojosu and R.I. Salawu, "A survey of wind energy potential in Nigeria", Solar \& Wind Technology, Vol. 7, No. 2/3, 1990, pp. 155-167.

[18] M. Harries, "Disseminating wind pumps in rural Kenya - meeting rural water needs using locally manufactured wind pumps", Energy Policy, Vol. 30, 2002, pp. 1087-1094.

[19] P.T. Smulders and J. de Jongh, "Wind water pumping: Status, prospects, and barriers", Renewable Energy, Vol. 5, 1994, pp. 587-594. 
[20] T.D. Short and P. Thompson, "Breaking the mould: solar water pumping - the challenges and the reality”, Solar Energy, Vol. 75, 2003, pp. 1-9.

[21] European Commission, "PVGIS Solar Irradiation Data - Africa", Photovoltaic Geographical Information System (PVGIS), [online], (updated 28 Aug 2007), Available from:

http://re.jrc.ec.europa.eu/pvgis/apps/radmonth.php?lang=en\&map=africa, [cited 3 Sep 2007].

[22] M.O. Faborode et al, "Assessment of seed-oil extraction technology in some selected states in Nigeria”, Technovation, Vol. 23, 2003, pp. 545-553.

[23] S.C.A. de Almeida et al, "Performance of a diesel generator fuelled with palm oil", Fuel, No. 81, 2002, pp. 2097-2102.

[24] L. Narvarte et al, "PV pumping analytical design and characteristics of boreholes", Solar Energy, Vol. 68, No. 1, 2000, pp. 49-56.

[25] Kyocera, "KC65T High Efficiency Multicrystal Photovoltaic Module", Kyocera Module Spec Sheets, [online], (updated 2007), Available from:

http://www.kyocerasolar.com/pdf/specsheets/KC65T.pdf, [cited 4 Sep 2007].

[26] Grundfos, "Grundfos Data Booklet - SQFlex", Grundfos SQFlex Downloads, [online], (updated 2007), Available from: http://net.grundfos.com/doc/webnet/sqflex/download/sqflex_databooklet.pdf, [cited 4 Sep 2007].

[27] S. Karekezi et al, "The potential contribution of non-electrical renewable energy technologies (RETs) to poverty reduction in East Africa", AFREPREN RETs Final Regional Version, Nairobi, December 2005.

[28] International Monetary Fund, "World Economic Outlook", World Economic and Financial Surveys, International Monetary Fund, April 2007.

[29] J. Mba-Afolabi, "The oil price hike blunder”, Newswatch, 18 January 1999, pp. 18-24.

[30] US Bureau of Labor Statistics, "Average Gasoline Price Data", Consumer Price Index, [online], (updated 2007), Available from: http://data.bls.gov/cgi-bin/dsrv?ap, [cited 5 Sep 2007]. 
Figure 1: Example Solar Pumping System [24]
Click here to download high resolution image

Figure 1: Example Solar Pumping System [24]
Click here to download high resolution image

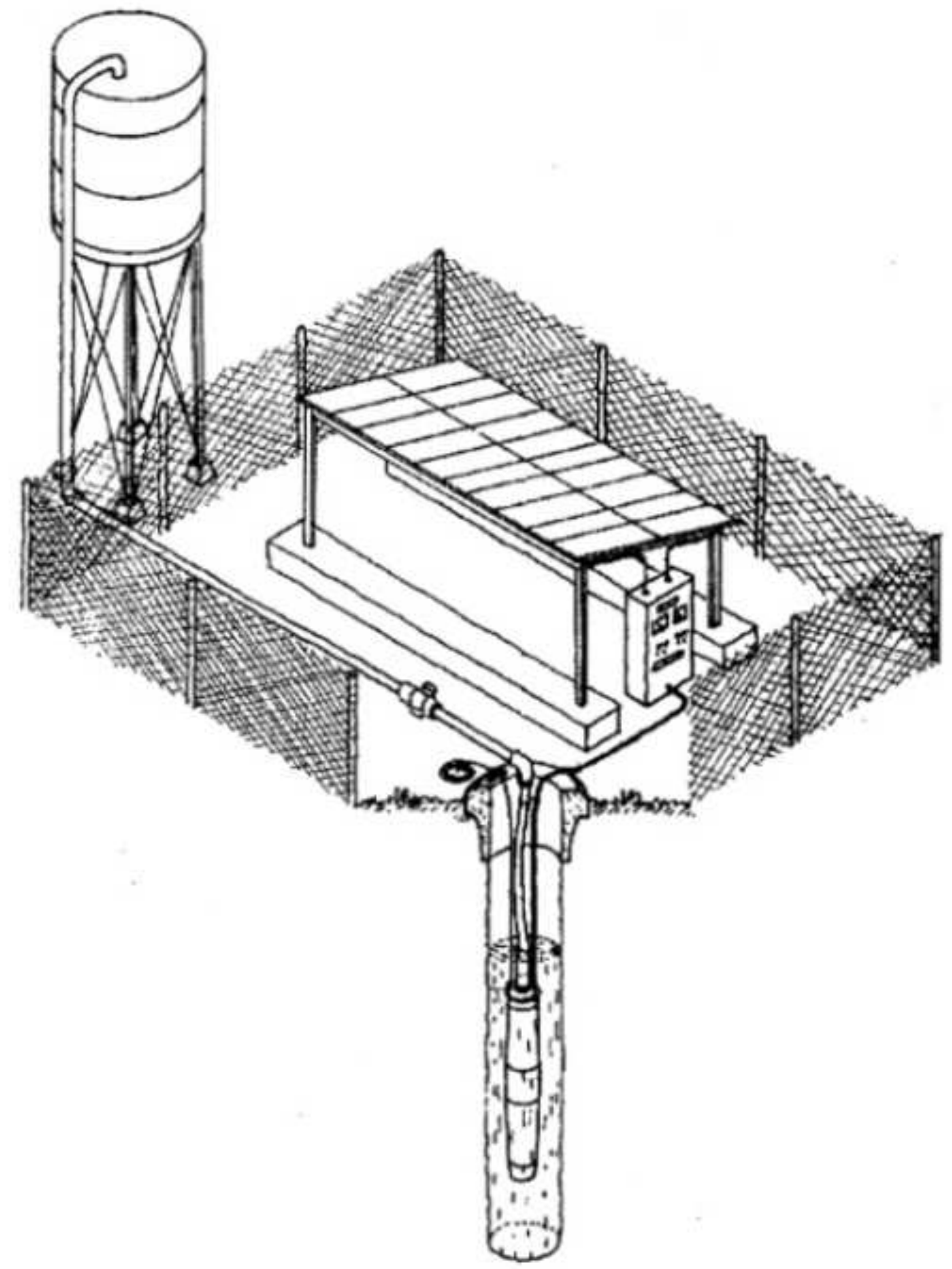

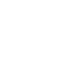

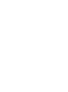

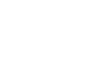
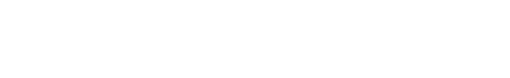

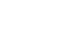

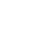

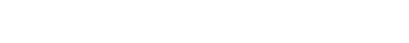
.

wiving 


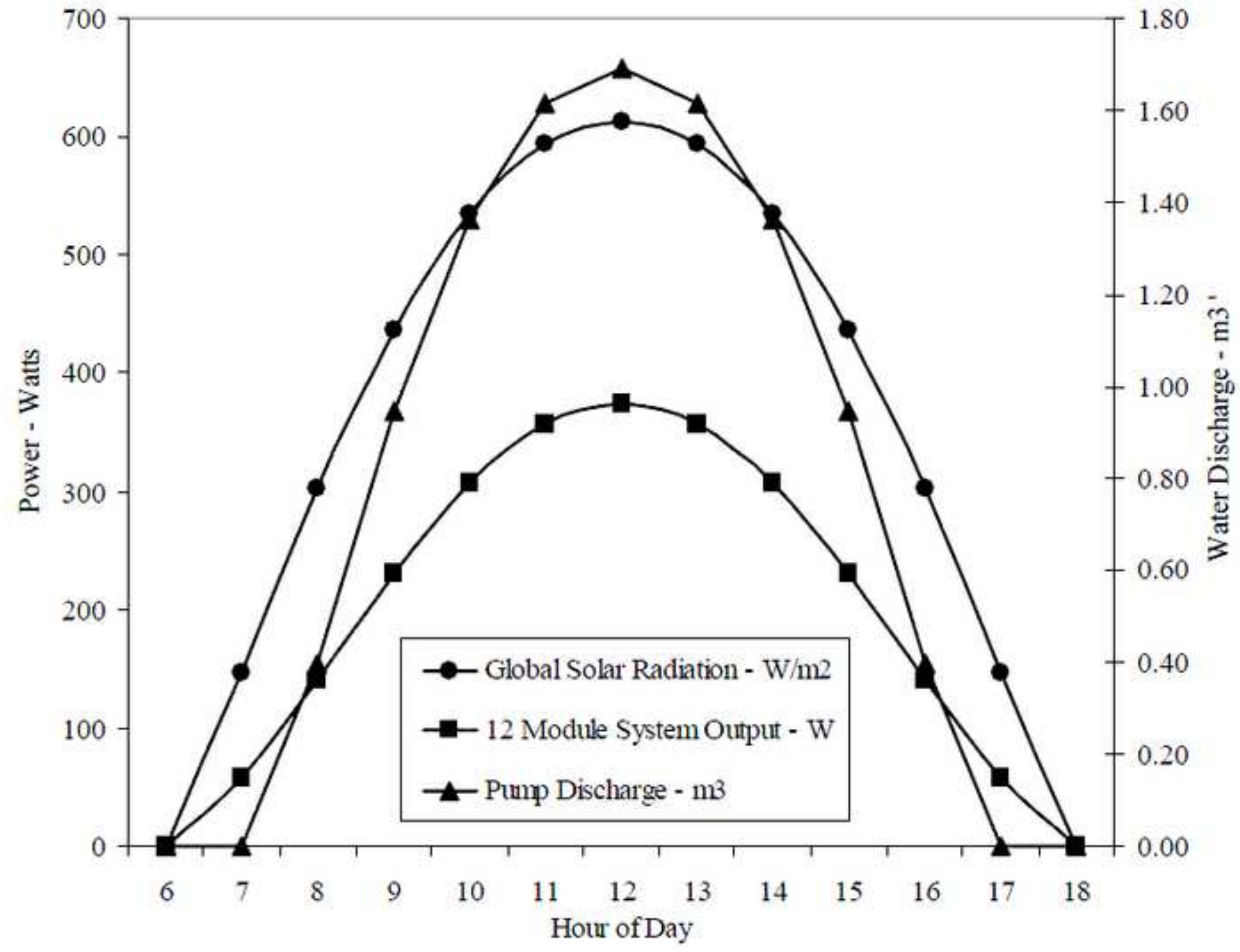


Figure 3: Example Kijito Wind Pump [10] Click here to download high resolution image

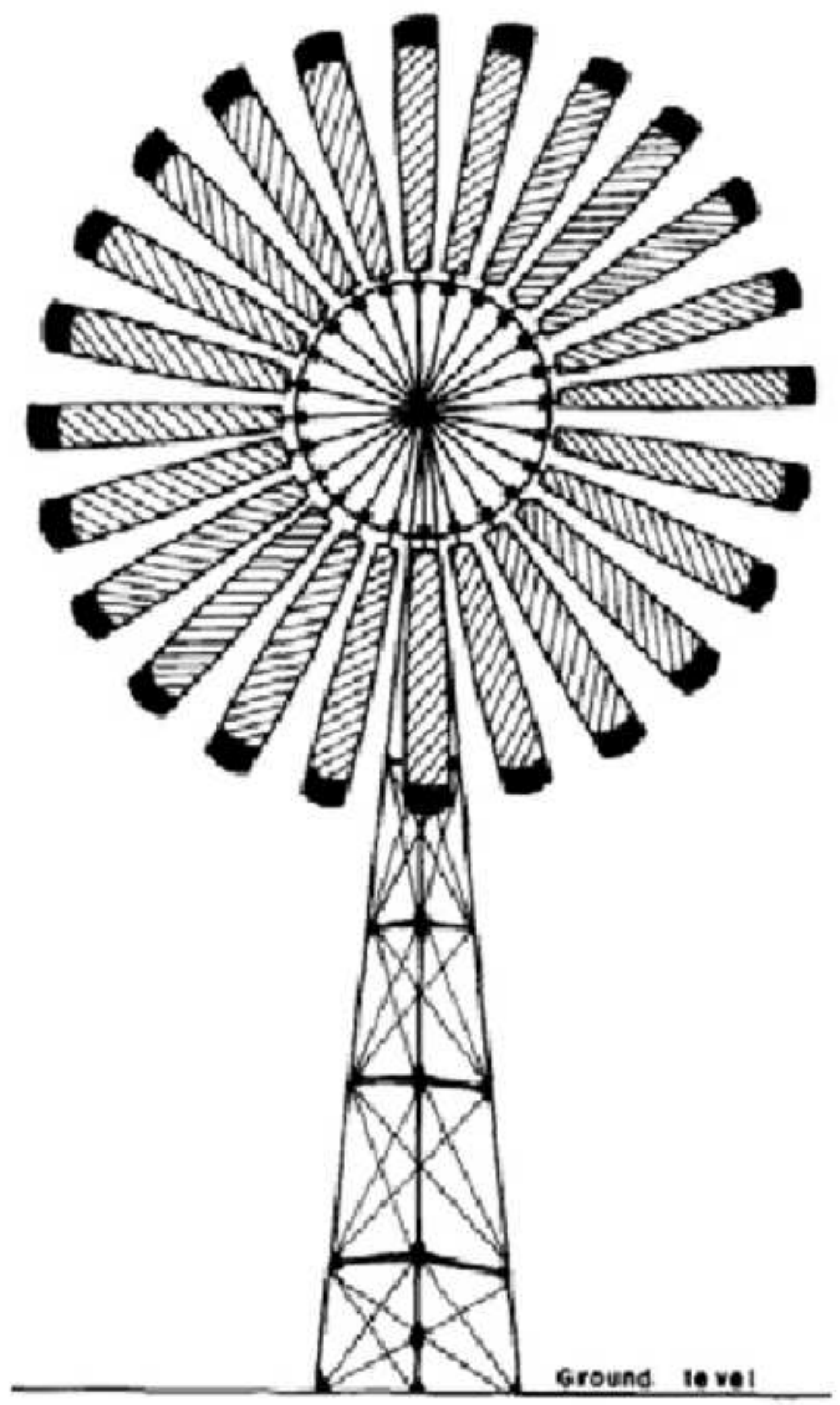




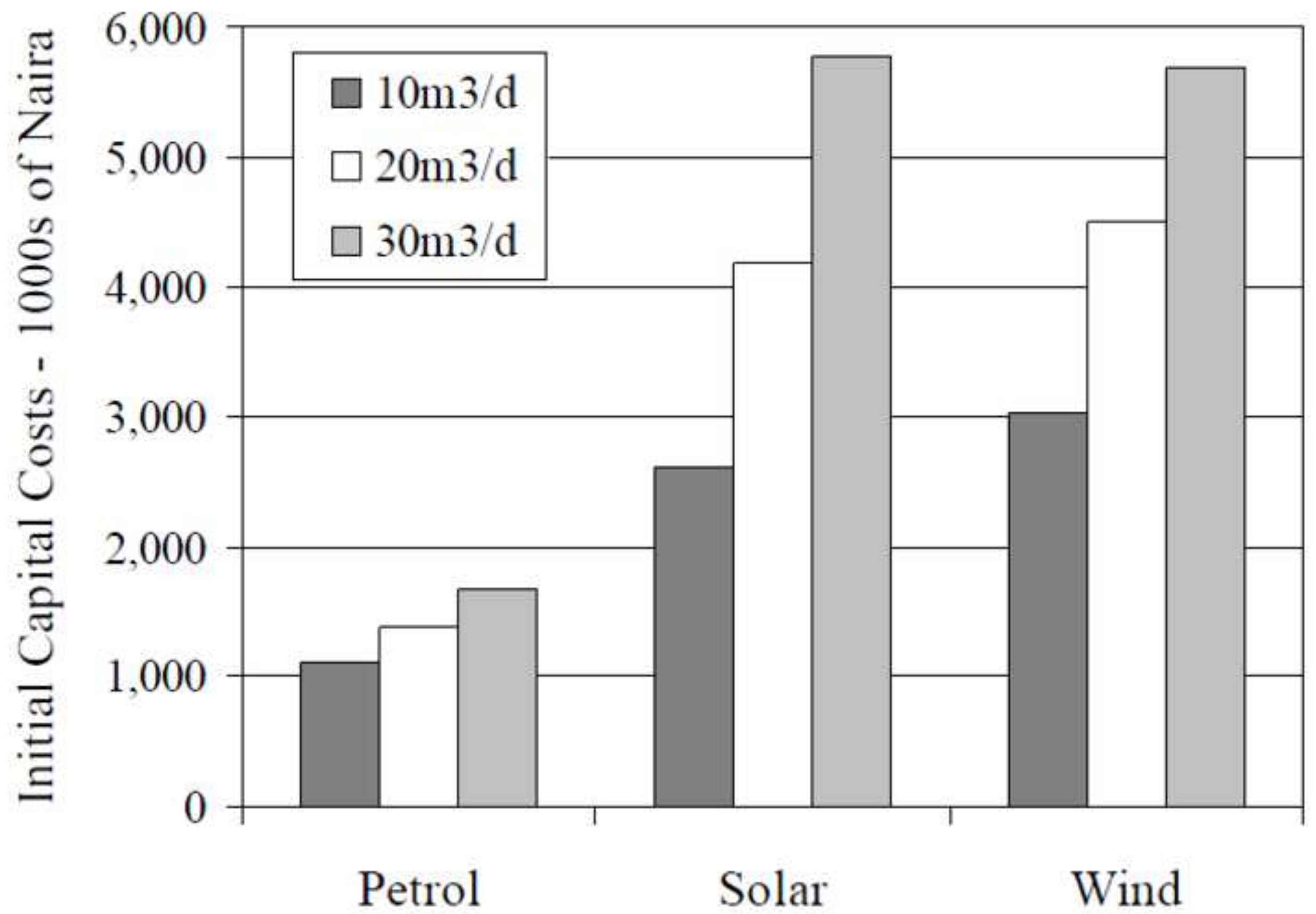




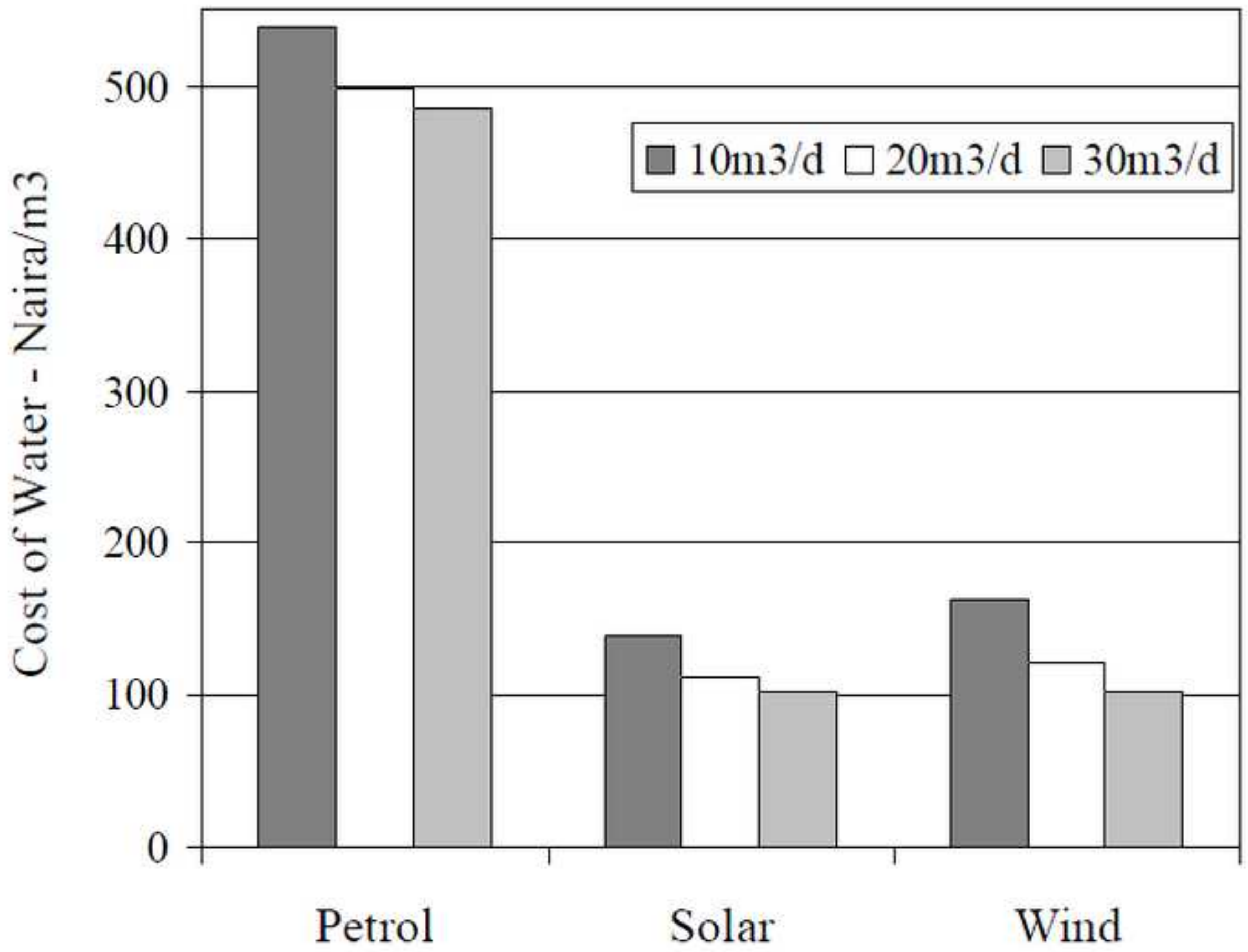


Figure 6: Effects of Inflation on the CoW for the $20 \mathrm{~m} 3$ system

Click here to download high resolution image

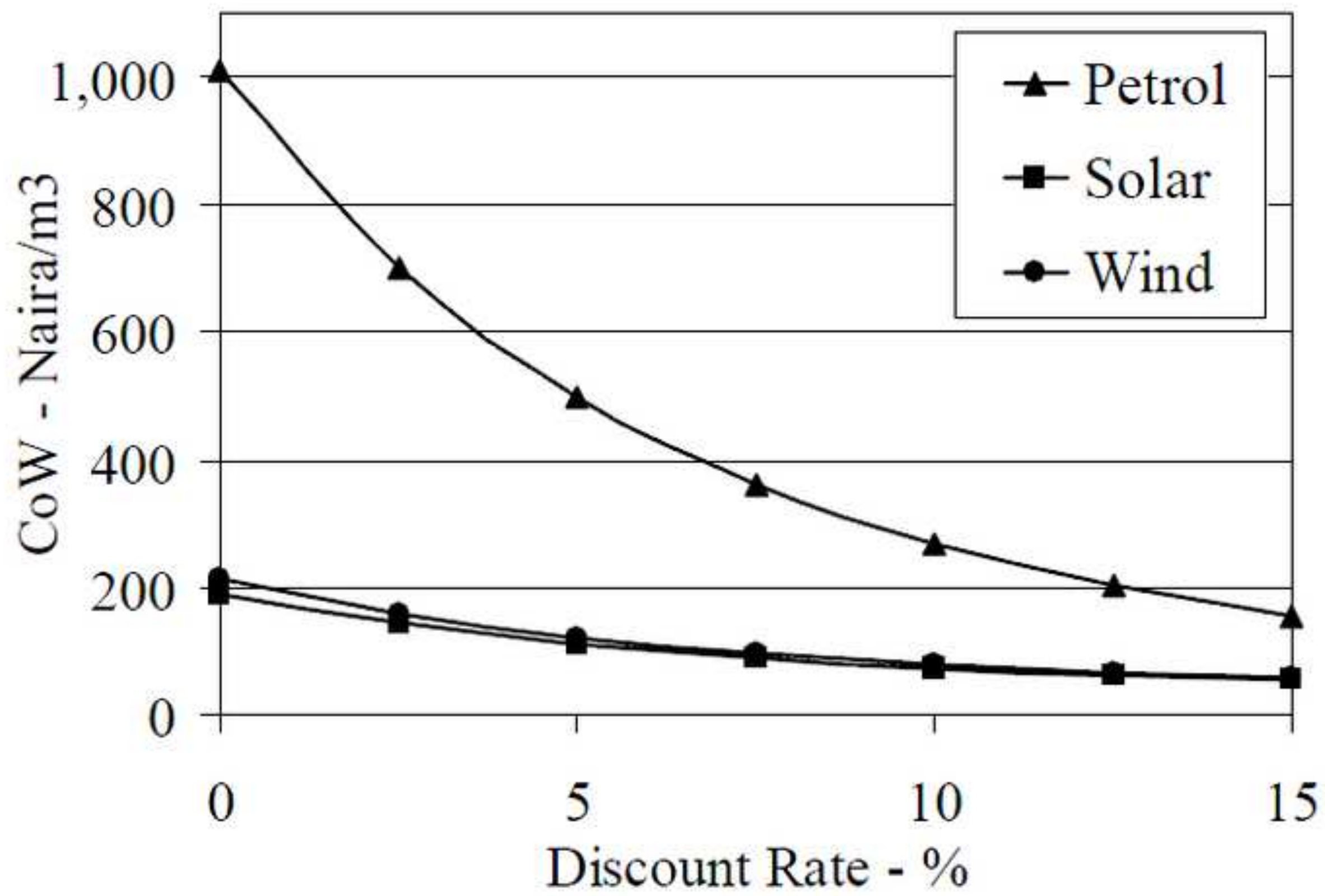


Figure 7: Effect of Discount Rate on the CoW for the $20 \mathrm{~m} 3$ system

Click here to download high resolution image

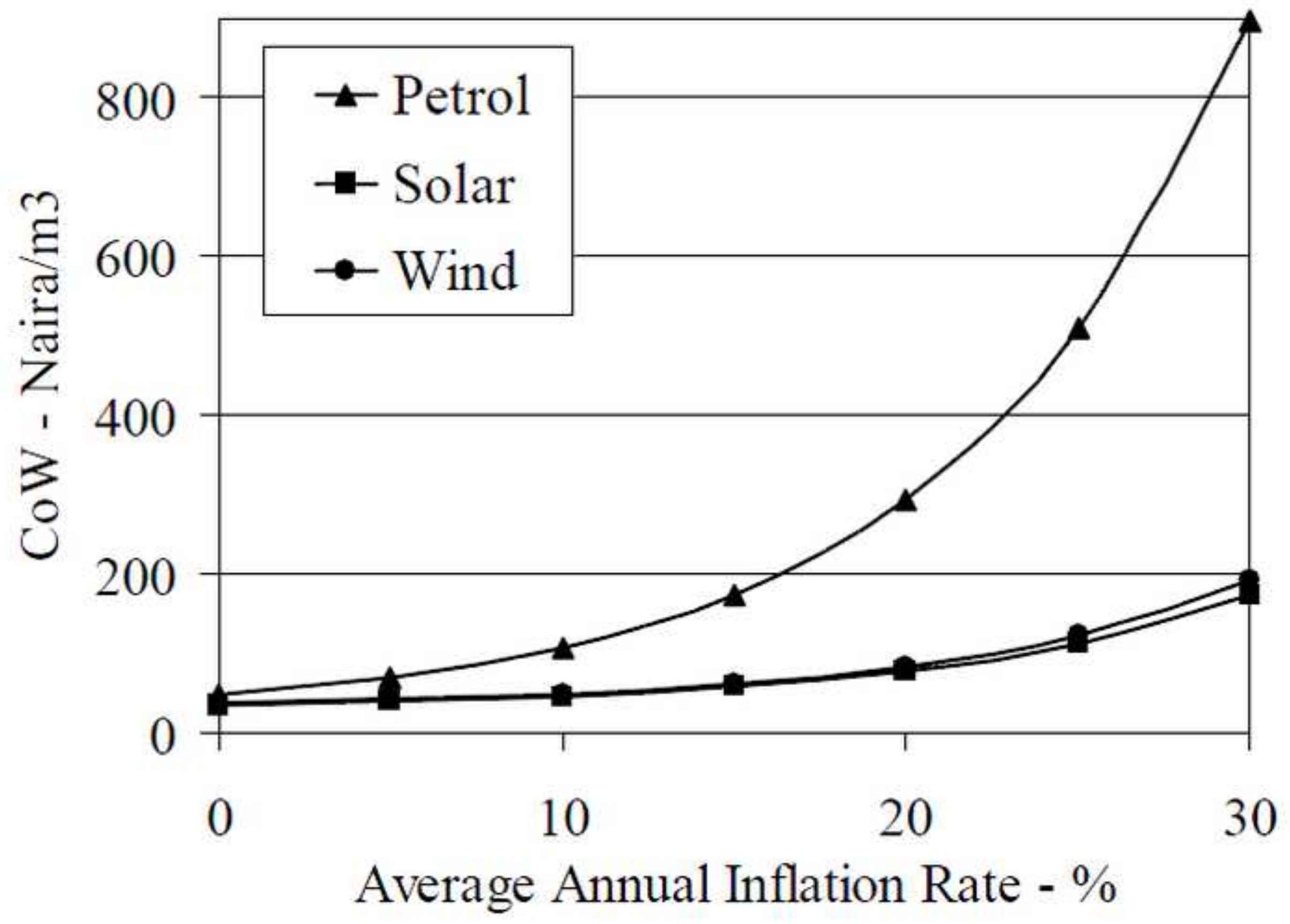




\begin{tabular}{lll}
\hline Location & $\begin{array}{l}\text { Average } \\
\text { Annual Wind } \\
\text { Speed }\end{array}$ & $\begin{array}{l}\text { Average Wind } \\
\text { Speed in Least } \\
\text { Windy Month }\end{array}$ \\
\hline Jos & $4.2 \mathrm{~m} / \mathrm{s}$ & $\begin{array}{l}3.7 \mathrm{~m} / \mathrm{s} \\
(\text { October) }\end{array}$ \\
Kaduna & $3.4 \mathrm{~m} / \mathrm{s}$ & $\begin{array}{l}2.3 \mathrm{~m} / \mathrm{s} \\
\text { (October) }\end{array}$ \\
Bauchi & $2.7 \mathrm{~m} / \mathrm{s}$ & $\begin{array}{l}2.3 \mathrm{~m} / \mathrm{s} \\
\text { (August) }\end{array}$ \\
\hline
\end{tabular}

Table 1: Wind Resource at a Height of $15 \mathrm{~m}[16,17]$ 


\begin{tabular}{lll}
\hline Location & $\begin{array}{l}\text { Monthly Mean } \\
\text { Daily Global } \\
\text { Radiation on a } \\
\text { Horizontal } \\
\text { Surface }\end{array}$ & $\begin{array}{l}\text { Daily } \\
\text { Radiation in } \\
\text { Least Sunny } \\
\text { Month } \\
\text { (August) }\end{array}$ \\
\hline Jos & $5.89 \mathrm{kWh} / \mathrm{m}^{2}$ & $4.65 \mathrm{kWh} / \mathrm{m}^{2}$ \\
Kaduna & $5.71 \mathrm{kWh} / \mathrm{m}^{2}$ & $4.39 \mathrm{kWh} / \mathrm{m}^{2}$ \\
Bauchi & $5.96 \mathrm{kWh} / \mathrm{m}^{2}$ & $4.96 \mathrm{kWh} / \mathrm{m}^{2}$ \\
\hline
\end{tabular}

Table 2: Solar Resource in Central Nigeria [6,21] 


\begin{tabular}{lc}
\hline Number of $70 \mathrm{~W}_{\mathrm{P}}$ Modules & $12\left(840 \mathrm{~W}_{\mathrm{P}}\right)$ \\
Area of Array & $6.3 \mathrm{~m}^{2}$ \\
$\begin{array}{l}\text { Average Output Per Day in } \\
\text { August }\end{array}$ & $2.56 \mathrm{kWh}$ \\
Battery Storage & None \\
Water Delivered in August & $10.3 \mathrm{~m}^{3} /$ day \\
Water Delivered in February & $15.8 \mathrm{~m}^{3} /$ day \\
\hline
\end{tabular}

Table $3: 10 \mathrm{~m}^{3} /$ day System Details 


\begin{tabular}{ll} 
Number of $70 \mathrm{~W}_{\mathrm{P}}$ Modules & $24\left(1680 \mathrm{~W}_{\mathrm{P}}\right)$ \\
Area of Array & $12.6 \mathrm{~m}^{2}$ \\
Average Output Per Day in August & $5.11 \mathrm{kWh}$ \\
Battery Storage & $200 \mathrm{Ah} @ 12 \mathrm{~V}$ \\
Water Delivered in August & $21.1 \mathrm{~m}^{3} /$ day \\
Water Delivered in February & $29.2 \mathrm{~m}^{3} /$ day \\
\hline
\end{tabular}

Table 4: 20m3/day System Details 


$\begin{array}{ll}\text { Number of } 70 \mathrm{~W}_{\mathrm{P}} \text { Modules } & 36\left(2520 \mathrm{~W}_{\mathrm{P}}\right) \\ \text { Area of Array } & 19.0 \mathrm{~m}^{2} \\ \text { Average Output Per Day in August } & 7.67 \mathrm{kWh} \\ \text { Battery Storage } & 400 \mathrm{Ah} @ 12 \mathrm{~V} \\ \text { Water Delivered in August } & 30.4 \mathrm{~m}^{3} / \text { day } \\ \text { Water Delivered in February } & 41.4 \mathrm{~m}^{3} / \text { day }\end{array}$

Table 5: 30m3/day System Details 


\begin{tabular}{llll}
\hline System & $\begin{array}{l}\text { Rotor diameter } \\
\text { required }\end{array}$ & $\begin{array}{l}\text { Water obtained in } \\
\text { October }(3.7 \mathrm{~m} / \mathrm{s} \text { mean } \\
\text { wind speed })\end{array}$ & $\begin{array}{l}\text { Water obtained in April } \\
(4.6 \mathrm{~m} / \mathrm{s} \text { mean wind } \\
\text { speed })\end{array}$ \\
$10 \mathrm{~m}^{3} /$ day & $4.9 \mathrm{~m}$ & $11-18 \mathrm{~m}^{3} /$ day & $27-37 \mathrm{~m}^{3} /$ day \\
$20 \mathrm{~m}^{3} /$ day & $6.1 \mathrm{~m}$ & $19-27 \mathrm{~m}^{3} /$ day & $42-57 \mathrm{~m}^{3} /$ day \\
$30 \mathrm{~m}^{3} /$ day & $7.4 \mathrm{~m}$ & $29-42 \mathrm{~m}^{3} /$ day & $65-89 \mathrm{~m}^{3} /$ day \\
\hline
\end{tabular}

Table 6: Candidate Wind Pump System Data [27] 